\section{(C) OPEN ACCESS}

\title{
Postoperative drug-induced priapism
}

\author{
Bartholomeus J G A Corten, ${ }^{1}{ }^{1}$ Frits Aarts, ${ }^{2}$ Ansgar S Harms, ${ }^{3}$ Jeroen Vogelaar ${ }^{2}$
}

\begin{abstract}
'Department of Surgery, Tweesteden Ziekenhuis, Tilburg, The Netherlands

${ }^{2}$ Department of Surgery, VieCuri Medisch Centrum, Venlo, The Netherlands

${ }^{3}$ Department of Anesthesiology, VieCuri Medisch Centrum, Venlo, The Netherlands
\end{abstract}

Correspondence to Mr Bartholomeus JGA Corten, bartcorten@gmail.com

Accepted 5 May 2017

\section{SUMMARY}

We presented a case of a postoperative patient with low-flow priapism, possibly initiated by propofolbased anaesthesia or epidural anaesthesia. The delay in diagnosing priapism resulted in emergency interventions with a partially successful effect and eventually permanent erectile dysfunction. Due to the delay in treatment, erectile dysfunction ensued and was manageable with medication; hence, the patient decided against a penile prosthesis.

\section{BACKGROUND}

Priapism is characterised by an unwanted prolonged erection and is a rare entity following abdominal surgery. ${ }^{12}$ Only a few case reports describe an association with anaesthesia, either general or epidural anaesthesia. ${ }^{3-7}$ The exact mechanism remains unclear, but prompt identification is vital to prevent permanent damage. Priapism is divided in two aetiological groups with their own level of urgency. Priapism may be secondary to a high-flow state resulting from direct trauma to the genitals, perineum or transurethral surgery. ${ }^{8}$ The trauma induces an arteriosinusoidal fistula with a good chance of recovery with treatment. In contrast, low-flow priapism is a more common, urgent presentation secondary to medication, haematological or neurological disease. ${ }^{9}$ In our case report, we expand briefly on the medication-induced priapism in relation to anaesthesia. This case illustrates the importance of prompt recognition and treatment of priapism to preserve erectile function.

\section{CASE PRESENTATION}

We present the case of a 58 -year-old Caucasian man who underwent a laparoscopic right-sided hemicolectomy because of colon carcinoma, under general (propofol-based) anaesthesia in combination with epidural anaesthesia. The surgery was successful, and patient recovery was excellent according to the Early Recovery After Surgery (ERAS) protocol. ${ }^{10}$ On arrival at the ward, the patient was hesitant to discuss penile complaints with attending female nurses. After 1 day of persistent painful erections, the patient notified the treating physician. On close inspection, painful engorgement of the penis in absence of sexual arousal was observed. The penis had an hourglass appearance of both corpora cavernosa (CC) distal to the base of the penis.

\section{INVESTIGATIONS}

Urology consult. A urologist was consulted and diagnosed the case as priapism, most likely low-flow, ${ }^{1}$ given the absence of a penile or perineal trauma or transurethral surgery. Bladder catheter was removed, and the epidural analgesia was discontinued. Evaluation after 4 hours showed no improvement of the erect state, therefore an emergency surgical intervention followed. At this time, the erection had persisted for approximately 48 hours.

\section{DIFFERENTIAL DIAGNOSIS}

The possible differential diagnoses of priapism include direct trauma, haematological diseases (eg, Sickle cell disease, unstable haemoglobin $\mathrm{Hb}$ Olmsted, thrombophilia, leukaemia), neurological disorders (eg, spinal cord injury, transverse myelitis and cerebrovascular disease), medication related (including antipsychotics, anticoagulants, anaesthesia and epidural analgesia) and others (eg, sildenafil citrate toxicity, Farbry's disease, neoplasm, total parenteral nutrition, appendicitis, amyloid and rabies). ${ }^{1}$

\section{TREATMENT}

A glans-to-CC shunt was performed. Introduction of two large syringes in the CC followed by irrigation over a period of 2 hours with a combination of heparin, methylene blue and sympathomimetic drugs. Concentrations of the infusion were as follows: 5000 IE heparin, $80 \mathrm{mg}$ ephedrine $+1 \mathrm{mg}$ epinephrine + two ampoules of methylene blue. Given the preceding delay, results of the procedure were mediocre, although acceptable with a flaccid penis state and relief of pain.

The day after the shunt procedure, the penis achieved a full erection once more. Onemilligram of phenylephrine was injected in the corpora without a significant effect. Given the long duration of erection and mediocre treatment results, it was presumed that postoperative erectile function would be unsatisfactory, with loss of function of the CC, causing erectile dysfunction.

\section{OUTCOME AND FOLLOW-UP}

As suspected, our patient had erectile dysfunction after the episode of postoperative priapism. Regarding options for erectile dysfunction treatment, penis prosthesis was considered. After 6 months, the erectile dysfunction was manageable with medication; hence, the patient decided against a penile prosthesis.

\section{DISCUSSION}

Priapism is defined as an unwanted, prolonged penile erection or clitoral swelling ${ }^{3}$ lasting for more than 6 hours, in the absence of sexual desire or 
Table 1 Overview of priapism

\begin{tabular}{|c|c|c|}
\hline & High flow (non-ischaemic) & Low flow (ischaemic) \\
\hline Frequency & Uncommon $(\sim 5 \%)$ & Common ( 95\%) \\
\hline Urgency & Non-urgent & Urgent \\
\hline \multirow[t]{7}{*}{ Aetiology } & Direct trauma to penis or perineum & Medication \\
\hline & Transurethral surgery & -Antipsychotics (eg, risperidone, olanzapine) \\
\hline & & -Epidural analgesia \\
\hline & & $\begin{array}{l}\text {-Anaesthesia (eg, propofol) } \\
\text {-Anticoagulants (intravenous heparin, oral coumarins) } \\
\text {-Phenothiaszines, paroxetine, fluoxetine and trazodone, } \\
\text { chronic cocaine abuse }\end{array}$ \\
\hline & & $\begin{array}{l}\text { Haematological disease (eg, Sickle cell disease, unstable } \\
\text { haemoglobin } \mathrm{Hb} \text { Olmsted, thrombophilia, leukaemia) }\end{array}$ \\
\hline & & $\begin{array}{l}\text { Neurological disorders (eg, spinal cord injury, transverse } \\
\text { myelitis and cerebrovascular disease) }\end{array}$ \\
\hline & & $\begin{array}{l}\text { Other (eg, sildenafil citrate toxicity, Farbry's disease, } \\
\text { neoplasm, total parenteral nutrition, appendicitis, amyloid } \\
\text { and rabies) }\end{array}$ \\
\hline Mechanism & Trauma-induced arteriosinusoidal fistula & Blood stasis due to venous outflow blockage \\
\hline Pain & Painless tender & Painful \\
\hline Plasticity & Semirigid & Hard \\
\hline Initial therapy & Watchful waiting, mechanical compression, ice packing & Intracavernous aspiration \\
\hline Secondary therapy & $\begin{array}{l}\text { Intracavernous aspiration or selective arterial } \\
\text { embolisation }\end{array}$ & Glans to corpora cavernosa shunt \\
\hline Last-resort therapy & & $\begin{array}{l}\text { Cavernosphenous or open proximal cavernospongiosum } \\
\text { shunt }\end{array}$ \\
\hline Recovery & Mostly excellent & May result in erectile dysfunction \\
\hline
\end{tabular}

stimulation. ${ }^{1}$ It is a rare complication after surgery, with only a few case reports available. ${ }^{3-7}$ Priapism is classified into high flow (non-ischaemic) and low flow (ischaemic), based on the blood flow in the penis (table 1$){ }^{1}$

High-flow priapism results from extensive arterial inflow due to injury of the corporal bodies creating an arteriosinusoidal fistula ${ }^{8}$ between the cavernous artery and the lacunar spaces of the CC. ${ }^{9}$ This injury results from direct trauma to the penis or perineum and usually cause the erection to be semirigid and painless compared with the low-flow state. In high-flow priapism, the penis is well oxygenated with blood gas values similar to arterial blood and can be confirmed by penile colour Doppler ultrasonography. ${ }^{9}$ Initial therapy consists of watchful waiting, mechanical compression, ice packing, aspiration of the cavernous bodies and irrigation with alfa-adrenoreceptor. ${ }^{11} 12$ If spontaneous detumescence fails, arterial embolisation of the cavernosa artery or internal pudendal artery should be considered. ${ }^{3}$ Paradoxically, epidural analgesia can be the cause or treatment of this condition. ${ }^{13}$

Low-flow or veno-occlusive priapism is by far the most common form, especially in paediatric populations. ${ }^{9}$ It results from blocking venous outflow and red blood cell stasis or sludging in haematological diseases. ${ }^{9}$ Frequent causes are use of medication (eg, antipsychotics, anaesthesia and epidural analgesia), haematological diseases (most common Sickle cell disease, leukaemia) and neurological disorders in paediatric population (eg, spinal cord injury, transverse myelitis and cerebrovascular disease). Pain originates from tissue ischaemia and smooth muscle hypoxia. Histopathological changes occur initially with interstitial oedema (up to 12 hours) resulting in endothelial thrombocytic adherence (by 24 hours) and finally lead to cell necrosis with or without fibrosis and calcifications (48 hours). ${ }^{114}$ Prompt diagnosis and treatment of this urological emergency is imperative. Failing to do so, causes irreversible damage with fibrosis and loss of penile tissue resulting in possible erectile dysfunction and impotence. ${ }^{9}$ Treatment encompasses conservative management, such as exercise, ice and ejaculation preceding surgical intervention. Surgery is aimed at restoring arterial inflow and increasing venous outflow of the cavernosal bodies. Primarily, intervention involves intracavernosal blood aspiration and warm saline irrigation with local sympathomimetic drugs. ${ }^{1}$ Aspiration and irrigation is successful in $77 \%$ of the cases. ${ }^{15}$ If there is no improvement, then shunt therapy should be considered, which has an overall success rate of approximately $75 \% .{ }^{16}$ Surgery consists of shunting the distal glans into the CC, using either a surgical blade (Ebbehoj procedure ${ }^{17}$ ) or a biopsy needle (Winter procedure $\left.{ }^{18}\right)$. If this procedure is unsuccessful, cavernosphenous ${ }^{19}$ or open proximal cavernospongiosum ${ }^{4}$ shunting should be considered.

In our case, we suggest that in this case persistent erection was secondary to low-flow stat. Moreover, we can only speculate about the factors responsible for the priapism. It was most likely caused by either general or epidural anaesthesia or by a vicious circle that was initiated by the anaesthesia and a persisting erectile state causing permanent damage to the cavernous bodies. Absence of direct trauma, pain and a full erection hinted a state of low flow. To our knowledge, the patient did not have any haematological diseases. Several case reports indicate that surgery can be a primary cause for priapism ${ }^{4-7}$; however, we regarded it as less likely, given the location of the operation field relative to normal erectile physiology. Failed conservative treatment and discontinuation of the thoracic epidural analgesia suggested another culprit. We suspect propofol (2,6-diisopropylphenol), which was used during induction and surgery, based on the clinical presentation and available literature. ${ }^{20-22}$ Unfortunately, the exact mechanism of propofol-induced and epidural analgesia priapism remains poorly understood. ${ }^{23}$ An autonomic imbalance between blockage of sympathetic or parasympathetic neuronal centres, responsible 
for physiological erections, underlies this pathophysiology. ${ }^{24}$ The anaesthetic effect of propofol might block the sympathetic vasoconstrictor action or enhance the parasympathetic vasodilatory action causing priapism. Propofol is also known to influence the nitric oxide-mediated smooth muscle relaxation, modulate on GABA-A and adrenal steroidogenesis which contributes to the physiology of an erection. ${ }^{25} 26$

A total of $1662 \mathrm{mg}$ of propofol administered by pump was used during the surgery. Additionally, intravenous $2.765 \mathrm{mg}$ remifentanyl, $60 \mathrm{mg}$ ropivacaine and $15 \mu \mathrm{g}$ sufentanil were administered via the epidural space. Postoperative epidural settings were $16 \mathrm{mg}$ ropivacaine and $4 \mu \mathrm{g}$ sufentanil hourly.

This case gave rise to staff education concerning priapism, facilitating prompt identification of this rare complication. This case outcome underscores the importance of early diagnosis in the face of preventing permanent damage. Patients may feel embarrassed and hesitant to report penile complains toward opposite gender medical professionals, and they could be afraid of stigmatisation.

We presented a case of a postoperative patient with low-flow priapism. We failed prompt identification and diagnosis, which resulted in emergency interventions with mediocre effect. Due to the delay in treatment, erectile dysfunction ensued and penis prosthesis was considered, although the patient decided against prosthesis hence the erectile dysfunction was manageable with medication.

\section{Learning points}

- Postoperative priapism is a rare but significant event that may result in irreversible damage to penile tissue.

- Postoperative priapism usually results from low-flow priapism.

- Prompt identification of priapism is pivotal for favourable outcomes.

- Patients may feel embarrassed and hesitant to report penile complaints towards opposite gender medical professionals, and they could be afraid of stigmatisation.

- Staff education concerning priapism may facilitate prompt identification.

Contributors BJGAC: writing of case report. FA: performing surgeon and writing. ASH: performing anesthetist and drug-related addition. JV: performing surgeon and revision writing

Competing interests None declared.

Patient consent Obtained.

Provenance and peer review Not commissioned; externally peer reviewed.

Open Access This is an Open Access article distributed in accordance with the Creative Commons Attribution Non Commercial (CC BY-NC 4.0) license, which permits others to distribute, remix, adapt, build upon this work non-commercially, and license their derivative works on different terms, provided the original work is properly cited and the use is non-commercial. See: http://creativecommons.org/ licenses/by-nc/4.0/

(C) BMJ Publishing Group Ltd (unless otherwise stated in the text of the article) 2017. All rights reserved. No commercial use is permitted unless otherwise expressly granted.

\section{REFERENCES}

1 Keoghane SR, Sullivan ME, Miller MA. The aetiology, pathogenesis and management of priapism. BJU Int 2002;90:149-54.

2 Monllor J, Taño F, Arteaga PR, et al. Priapism of the clitoris. Eur Urol 1996;30:521-2.

3 Tuygun C, Guvercinci M, Conkbayir I, et al. Post-surgical high-flow priapism treated by embolization. International Journal of Urology 2007;14:1107-8.

4 Mon Martín F, Guil Ortiz B, Delgado Plasencia L, et al. High flux priapism, an exceptional complication of rectal cancer surgery. Cir Esp 2016;94:116-8.

5 Arbanas G. A case of painful erections after pelvic surgery. Arch Sex Behav 2011:40:465-7.

6 Tuygun C, Guvercinci M, Conkbayir I, et al. Post-surgical high-flow priapism treated by embolization. Int J Urol 2007;14:1107-8.

7 Hishmeh S, DiMaio FR. Priapism as a complication after total hip arthroplasty: a case report and review of the literature. Orthopedics 2008;31:397.

8 Pautler SE, Brock GB. Priapism. from Priapus to the present time. Urol Clin North Am 2001;28:391.

9 Fuentes EJ, Garcia S, Garrido M, et al. Successful treatment of propofol-induced priapism with distal glans to corporal cavernosal shunt. Urology 2009;74:113-5

10 Gustafsson UO, Scott MJ, Schwenk W, et al. Guidelines for perioperative care in elective colonic surgery: enhanced Recovery after Surgery (ERAS $®)$ Society recommendations. Clin Nutr 2012:31:783-800.

11 Bastuba MD, Saenz de Tejada I, Dinlenc CZ, et al. Arterial priapism: diagnosis, treatment and long-term followup. J Urol 1994;151:1231

12 Kim SC, Park SH, Yang SH. Treatment of posttraumatic chronic high-flow priapisms by superselective embolization of cavernous artery with autologous clot. J Trauma 1996:40:462-5.

13 McHardy P, McDonnell C, Lorenzo AJ, et al. Management of priapism in a child with sickle cell Anemia; successful outcome using epidural analgesia. Canadian Journal of Anesthesia/Journal canadien d'anesthésie 2007;54:642-5.

14 Spycher MA, Hauri D. The ultrastructure of the erectile tissue in priapism. J Urol 1986;135:142-7.

15 Montague DK, Jarow J, Broderick GA, et al. American Urological Association guideline on the management of priapism. J Urol 2003;170:1318-24.

16 Nixon RG, O'Connor JL, Milam DF. Efficacy of shunt surgery for refractory low flow priapism: a report on the incidence of failed detumescence and erectile dysfunction. J Urol 2003;170:883-6.

17 Ercole CJ, Pontes JE, Pierce JM. Changing surgical concepts in the treatment of priapism. J Urol 1981;125:210-1.

18 Winter CC. Priapism cured by creation of fistulas between glans penis and corpora cavernosa. J Urol 1978;119:227-8.

19 Grayhack JT, McCullough W, O'CONOR VJ, et al. Venous bypass to control priapism. Invest Urol 1964;1:509-13.

20 Quackles R. Cure of a patient suffering from priapism by cavernospongiosa anastamosis. Acta Urol Belg 1964;32:5-13.

21 Vesta KS, Martina SD, Kozlowski EA. Propofol-induced priapism, a case confirmed with rechallenge. Ann Pharmacother 2006;40:980-2.

22 Senthilkumaran S, Shah S, Ganapathy Subramanian, et al. Propofol and priapism. Indian J Pharmacol 2010:42:238-9.

23 Fransen van de Putte EE, Ananias HJ, Gi NP, et al. Priapism following continuous thoracic epidural anaesthesia: emergency or a benign condition? Acta Anaesthesiol Scand 2014;58:903-5.

24 Giuliano F. Neurophysiology of erection and ejaculation. J Sex Med 2011;8(Suppl 4):310-5.

25 Vasileiou I, Xanthos T, Koudouna E, et al. Propofol: a review of its non-anaesthetic effects. Eur J Pharmacol 2009:605:1-8.

26 Andersson KE. Pharmacology of penile erection. Pharmacol Rev 2001:53:417-50. 
Copyright 2017 BMJ Publishing Group. All rights reserved. For permission to reuse any of this content visit http://group.bmj.com/group/rights-licensing/permissions.

BMJ Case Report Fellows may re-use this article for personal use and teaching without any further permission.

Become a Fellow of BMJ Case Reports today and you can:

- Submit as many cases as you like

- Enjoy fast sympathetic peer review and rapid publication of accepted articles

Access all the published articles

- Re-use any of the published material for personal use and teaching without further permission

For information on Institutional Fellowships contact consortiasales@bmjgroup.com

Visit casereports.bmj.com for more articles like this and to become a Fellow 